\title{
The Effect of Antiseptics on Adipose-Derived Stem Cells
}

Bong-Sung Kim, M.D. Veronica Ott

Arne Hendrick Boecker, M.D.

Jan-Philipp Stromps, M.D. Nora Emilie Paul, Ph.D. Ziyad Alharbi, M.D., Ph.D.

Ercan Cakmak, M.D. Jürgen Bernhagen, Ph.D. Richard Bucala, M.D., Ph.D. Norbert Pallua, M.D., Ph.D.

Aachen and Munich, Germany; and New Haven, Conn.

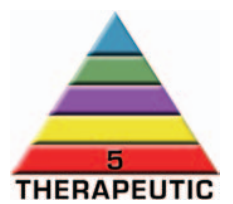

Background: Although chemical antiseptics are the most basic measure to control wound infection and frequently come into contact with subcutaneous adipose tissue, no studies have evaluated their toxicity on adipose tissue and its cell fractions. In the present study, the effects of five different antiseptics on adipose-derived stem cells were evaluated.

Methods: Human adipose-derived stem cells were harvested from healthy donors. Adipose-derived stem cell viability was measured after treatment with different concentrations of antiseptics over 5 days. Furthermore, the effect on the proliferation, adipogenic differentiation, and apoptosis/necrosis of adipose-derived stem cells was analyzed. Finally, the mRNA expression of the stem cell markers CD29, CD34, CD73, CD90, and CD105 was detected.

Results: Octenisept and Betaisodona significantly reduced cell proliferation and differentiation and led to considerable adipose-derived stem cell necrosis. Octenisept decreased stem cell viability at the lowest concentrations tested, and all stem cell markers were down-regulated by Octeniseptr and Betaisodona. Lavasept and Prontosan both led to reduced stem cell viability, proliferation, and differentiation, and increased apoptosis/necrosis, although the effects were less pronounced compared with Octenisept and Betaisodona. Adipose-derived stem cells survived treatment with mafenide acetate even at high concentrations, and mafenide acetate showed minimal negative effects on their proliferation, adipogenic differentiation, cell death, and stem cell marker expression.

Conclusions: Mafenide acetate may be regarded as a feasible antiseptic for the treatment of wounds with exposed adipose tissue because of its low adiposederived stem cell toxicity. Lavasept and Prontosan are possible alternatives to mafenide acetate. Octenisept and Betaisodona, by contrast, may be used only in highly diluted solutions. (Plast. Reconstr. Surg. 139: 625, 2017.)

CLINICAL QUESTION/LEVEL OF EVIDENCE: Therapeutic, V.
T he skin forms a natural barrier that protects underlying tissue; once the skin barrier is broken, wound repair is induced by a meticulously orchestrated host response. ${ }^{1}$ Nonhealing wounds represent a major health care burden and

From the Department of Plastic and Reconstructive Surgery, Hand Surgery-Burn Center, Medical Faculty, the Institute of Biochemistry and Molecular Cell Biology, RWTH Aachen University; the Institute for Stroke and Dementia Research, Klinikum der Universität München, Ludwig-MaximiliansUniversity; the Munich Cluster for Systems Neurology ( $\mathrm{SyN}$ ergy); and the Department of Medicine, Yale University School of Medicine.

Received for publication December 5, 2015; accepted June 21, 2016 .

Copyright $@ 2017$ by the American Society of Plastic Surgeons

DOI: 10.1097/PRS.0000000000003125 affect approximately 1 percent of the population, ${ }^{2}$ and the leading threat to all wounds is infection by microorganisms. ${ }^{3}$ Chemical antiseptics are the favored method in clinical routine because of

Disclosure: None of the authors has a financial interest in any of the products, devices, or drugs mentioned in this article.

Supplemental digital content is available for this article. A direct URL citation appears in the text; simply type the URL address into any Web browser to access this content. A clickable link to the material is provided in the HTML text of this article on the Journal's website (www.PRSJournal.com). 
their effectiveness, simple applicability, and low costs. ${ }^{4,5}$

To date, most authors have limited investigation of the toxicity of antiseptics to skin cells (i.e., keratinocytes and fibroblasts) and adapted the concentrations of the reagents accordingly. ${ }^{6-10}$ With the exception of superficial wounds, however, the tissue layers underneath the skin also are affected and prone to bacterial contamination. Subcutaneous adipose tissue actively participates in wound repair by the delivery of cytokines and the differentiation of progenitor cells. ${ }^{11-16}$ Adipose tissue has been discovered to be a rich source of adipose-derived stem cells, which possess considerable regenerative potential ${ }^{17}$ and play a welldocumented beneficial role in wound repair. ${ }^{2,18}$

Adipose tissue frequently comes into contact with chemical antiseptics during the treatment of plastic surgical patients, especially during surgical preparation of open or infected wounds that entails direct contact. Additional scenarios are the rinsing of wounds and antiseptic dressings for the treatment of critical wounds. However, no studies have examined possible toxic effects of antiseptics on adiposederived stem cells. In the present study, we measured the effect of five commercially available antiseptics on the viability, proliferation, cell death, expression of stem cell markers, and differentiation of cultured adipose-derived stem cells with the goal of identifying auspicious antiseptics for the treatment of wounds with exposure of adipose tissue.

\section{PATIENTS AND METHODS}

\section{Human Samples}

Adipose tissue was harvested from 13 healthy patients (six men and seven women), with a mean age $38.7 \pm 4.4$ years, undergoing surgery at the Department of Plastic and Reconstructive Surgery, Hand Surgery-Burn Center at the University Hospital in Aachen. The study outline is illustrated in Figure 1 . The study was approved by the regional ethics committee (EK163/07) and all experiments were conducted in compliance with the

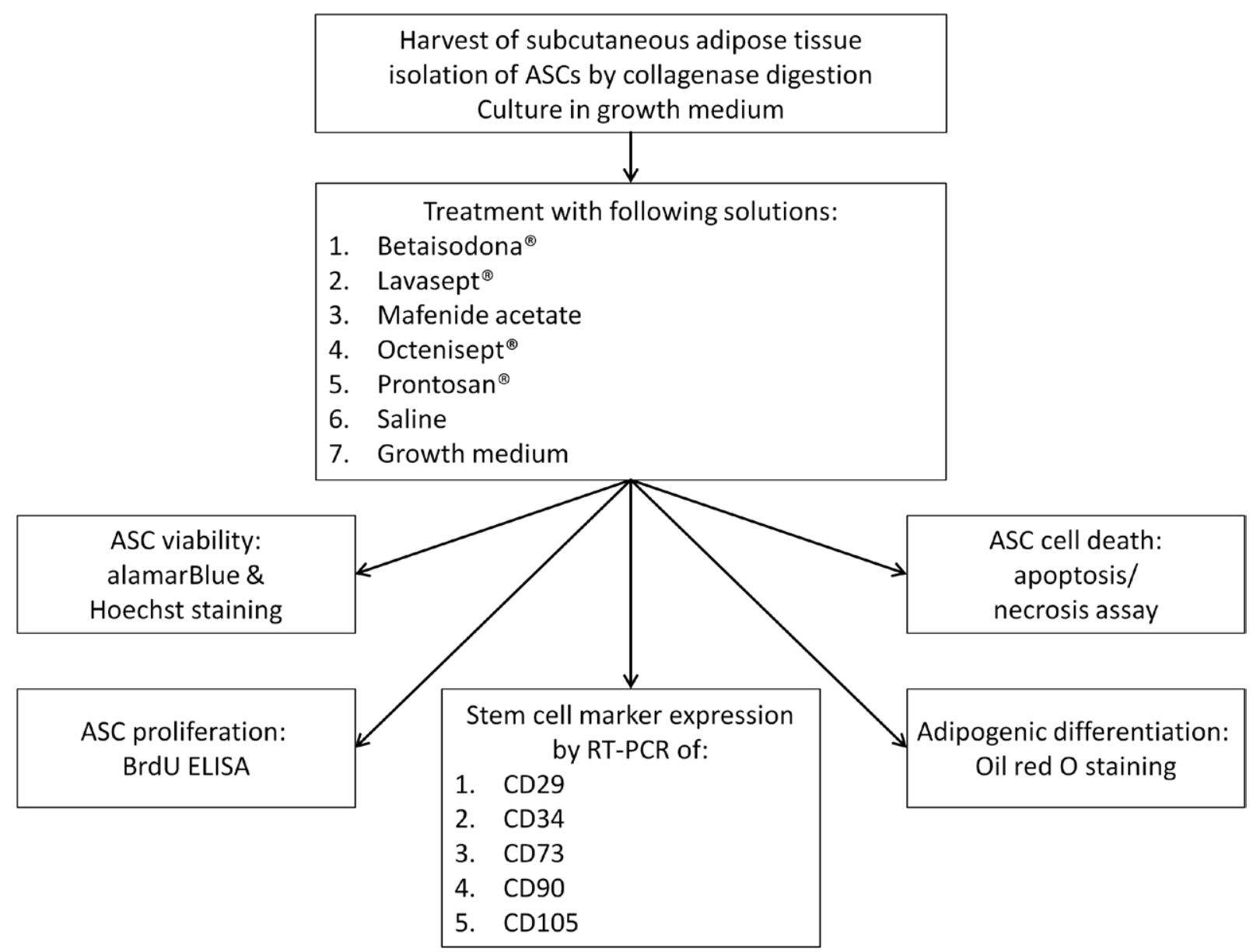

Fig. 1. Schematic diagram of the experimental design. ASCS, adipose-derived stem cells; ELISA, enzyme-linked immunosorbent assay; $R T-P C R$, real-time polymerase chain reaction. 
principles outlined in the Declaration of Helsinki. Samples were not mixed and each experiment was repeated once. Each of the repeated experiments was performed in duplicate and the statistical analysis is based on the mean of the independent repeated experiments.

\section{Antiseptics Used}

The antiseptics Betaisodona, Lavasept, mafenide acetate, Octenisept, and Prontosan were used in our study (Table 1).

\section{Isolation of Adipose-Derived Stem Cells}

Lipoaspirates were harvested according to the Coleman protocol. ${ }^{19}$ Adipose-derived stem cells were harvested as described earlier. ${ }^{20}$

\section{Treatment with Antiseptics and Measurement of Adipose-Derived Stem Cell Viability}

Cell proliferation was measured by the alamarBlue assay (AbDSerotec, Oxford, United Kingdom) following the manufacturer's guidelines. Adipose-derived stem cells were cultured in 24-well plates overnight. The following day, cell viability was measured by alamarBlue. This value was set as 100 percent and served as the reference for all following measurements. After the measurement, the medium was removed and the cells were incubated for 5 minutes with antiseptics in the following concentrations: $1,2.5,5,7.5,10$, and $25 \%$ of the original concentration provided by the manufacturer. We also treated cells with undiluted saline $(0.9 \%$ sodium chloride). Growth medium served as a negative control. Cell viability was examined after 1,3 , and 5 days.

\section{Hoechst 33342 Staining}

Five days after treatment of adipose-derived stem cells with antiseptics, saline, and medium, adiposederived stem cells were stained with Hoechst 33342 and cells were fixed with $4 \%$ paraformaldehyde. Fluorescence microscopy was performed by an inverted phase contrast microscope (Leica DMI4000 B; Leica Microsystems, Buffalo Grove, Ill.).

\section{Measurement of Adipose-Derived Stem Cell Proliferation by Bromodeoxyuridine Enzyme- Linked Immunosorbent Assay}

Proliferation of adipose-derived stem cells was analyzed by the CytoSelect Bromodeoxyuridine Cell Proliferation ELISA Kit (Cell Biolabs, Inc., San Diego, Calif.) according to the manufacturer's instructions in 96-well plates. Cells were treated with $7.5 \%$ antiseptics, saline, and medium for 5 minutes.

\section{Measurement of Apoptosis and Necrosis}

Necrosis and apoptosis were detected with the Pacific Blue Annexin V Apoptosis Detection Kit (Biolegend, San Diego, Calif.). Adipose-derived stem cells were treated with antiseptics at a concentration of $7.5 \%$, saline, and medium for 5 minutes. Cells were stained with Pacific Blue-labeled annexin $\mathrm{V}$ and 7-aminoactinomycin D. Stained cells were evaluated by flow cytometry on a LSR II cytometer (BD Biosciences, San Jose, Calif.).

Table 1. Ingredients and Antimicrobial Efficacy of the Antiseptics Used

\begin{tabular}{|c|c|c|}
\hline Name and Manufacturer & Ingredients & Antimicrobial Efficacy \\
\hline $\begin{array}{l}\text { Betaisodona } \\
\text { (Mundipharma Research, Limburg, } \\
\text { Germany) }\end{array}$ & $\begin{array}{l}100 \mathrm{ml} \text { of the solution contains } 10 \mathrm{~g} \text { of } \\
\text { povidone-iodine complex and } 11 \% \\
\text { available iodine. }\end{array}$ & $\begin{array}{l}\text { Viruses, Gram-positive and Gram-negative } \\
\text { bacteria, tubercle bacilli, fungi, protozoa, } \\
\text { methicillin-resistant Staphylococcus aureus }\end{array}$ \\
\hline $\begin{array}{l}\text { Lavasept concentrate } \\
\text { (B. Braun Melsungen AG, Melsungen, } \\
\text { Germany) }\end{array}$ & $\begin{array}{l}100 \mathrm{ml} \text { of the concentrate contains } 20 \mathrm{~g} \\
\text { of polyhexanide and } 1 \mathrm{~g} \text { of polyethyl- } \\
\text { ene glycol } 4000 \text {. The concentrate was } \\
\text { diluted to a polyhexanide concentra- } \\
\text { tion of } 0.04 \% \text { as recommended by the } \\
\text { manufacturer. }\end{array}$ & $\begin{array}{l}\text { Fungi and bacteria including staphylococci, } \\
\text { enterococci, Pseudomonas aeruginosa, } \\
\text { intestinal bacterial such as Escherichia coli }\end{array}$ \\
\hline $\begin{array}{l}\text { Mafenide acetate } \\
\text { (Fagron GmbH \& Co. KG, Barsbüttel, } \\
\text { Germany) }\end{array}$ & $\begin{array}{l}\text { Powder was diluted in } 0.9 \% \text { sodium } \\
\text { chloride to a final concentration of } 5 \% \\
\text { mafenide acetate as recommended by } \\
\text { the manufacturer. }\end{array}$ & $\begin{array}{l}\text { Gram-negative and Gram-positive bacteria, } \\
\text { Pseudomonas aeruginosa, some anaerobic } \\
\text { organisms, molds }\end{array}$ \\
\hline $\begin{array}{l}\text { Octenisept } \\
\text { (Schülke \& Mayr GmbH, Norderstedt, } \\
\text { Germany) }\end{array}$ & $\begin{array}{l}100 \mathrm{ml} \text { of the solution contains } 0.1 \mathrm{~g} \text { of } \\
\text { octenidine dihydrochloride and } 2 \mathrm{~g} \text { of } \\
\text { 2-phenoxyethanol. }\end{array}$ & $\begin{array}{l}\text { Chlamydia, mycoplasma, fungi, yeasts, pro- } \\
\text { tozoa, viruses (herpes simplex, hepatitis } \\
\text { B virus, hepatitis C virus, human immu- } \\
\text { nodeficiency virus), and importantly also } \\
\text { methicillin-resistant Staphylococcus aureus }\end{array}$ \\
\hline $\begin{array}{l}\text { Prontosan } \\
\text { (B. Braun Melsungen AG, Melsungen, } \\
\text { Germany) }\end{array}$ & $\begin{array}{l}\text { Solution contains } 0.1 \% \text { undecylenamido- } \\
\text { propyl betaine and } 0.1 \% \text { polyhexanide. }\end{array}$ & $\begin{array}{l}\text { Fungi and bacteria including staphylococci, } \\
\text { enterococci, Pseudomonas aeruginosa, } \\
\text { intestinal bacterial such as Escherichia coli }\end{array}$ \\
\hline
\end{tabular}


Plastic and Reconstructive Surgery • March 2017

Isolation of mRNA, Reverse Transcription, and Real-Time Polymerase Chain Reaction

Messenger RNA from whole adipose tissue for real-time polymerase chain reaction was prepared by the RNeasy Mini Kit (Qiagen NV, Venlo, The Netherlands) and reverse transcription into cDNA was performed by the First Strand cDNA Synthesis Kit (Thermo Fisher Scientific, Inc., Waltham, Mass.) following the manufacturers' instructions. Quantitative realtime polymerase chain reaction was carried out with the iTaq Universal SYBR Green Supermix (Bio-Rad Laboratories, Inc., Irvine, Calif.) on a C1000TM Thermal Cycler (Bio-Rad). Primers used in the assay are listed in Table 2. Data were normalized to the housekeeping gene glyceraldehyde 3-phosphate dehydrogenase (GAPDH). Changes in gene expression were compared to adipose-derived stem cells treated with growth medium. Treatment with $1-\mu \mathrm{M}$ staurosporine and $500-\mu \mathrm{M}$ hydrogen peroxide (both from Sigma Aldrich Chemie GmbH, Taufkirchen, Germany) served as apoptosis and necrosis controls.

\section{Adipose-Derived Stem Cell Differentiation and Oil Red O Staining}

Adipogenic differentiation of cultured adipose-derived stem cells was induced as reported earlier. ${ }^{21}$ Over the whole differentiation period, medium was supplemented with $0.05 \%$ antiseptics/saline.

\section{Statistical Analysis}

The software Prism, version 5.03 (GraphPad Software, Inc., La Jolla, Calif.) was used for data analysis. One-way analysis of variance was performed for multiple comparisons. Two-way repeated measures analysis of variance with a post hoc multiple comparison test (Bonferroni) was used for analyzing adipose-derived stem cell viability over time. Data are shown as means \pm SEM. A value of $p<0.05$ was considered significant.

\section{RESULTS}

\section{Antiseptics Influence the Viability of Adipose-Derived Stem Cells}

The viability of adipose-derived stem cells treated by antiseptics was measured by the alamarBlue assay (Fig. 2). For all antiseptics, a dose-dependent reduction of cell viability was observed. Octenisept showed the highest cell toxicity. Adipose-derived stem cells treated with only $1 \%$ Octenisept did not recover completely. A 2.5\% Octenisept solution resulted in complete cell death $(2.5,5$, and $10 \%)$. [See Figure, Supplemental Digital Content 1, which shows the influence of antiseptics on the viability of adipose-derived stem cells. Cultured adipose-derived stem cells were treated with $2.5 \%$ (above), $5 \%$ (center), and $10 \%$ (below) solutions of Octenisept, Betaisodona, Prontosan, Lavasept, mafenide acetate, or normal saline. Growth medium served as a control. The viability of adipose-derived stem cells was evaluated by the alamarBlue assay after 1, 3, and 5 days. The viability of adipose-derived stem cells before treatment was set as 100 percent. Data are presented in means \pm SEM. Significant differences when compared to other groups are indicated by letters in lowercase. Normal (not bold/italicized), $p<0.05$; bold, $p<0.01 ;$ bold and italicized, $p<0.001 ; o$, Octenisept; $b$, Betaisodona; $p$, Prontosan; $l$, Lavasept; $m$, mafenide acetate; $s$, saline; $g$, growth medium, http://links.lww.com/PRS/ C65.] Cell viability was not significantly reduced in adipose-derived stem cells treated with $1 \%$ and $2.5 \%$ Betaisodona, whereas a $5 \%$ solution led to marked cytotoxicity. Similarly, adiposederived stem cells treated with 5\% Prontosan recovered from the initial exposure, whereas concentrations greater than or equal to $7.5 \%$ led to irreversible cell death. Lavasept did not show significant cytotoxicity at concentrations less than or equal to $5 \%$. A solution of $7.5 \%$ and $10 \%$ caused a reduction of adipose-derived stem cell viability but cells still recovered. Only a $25 \%$ solution of Lavasept led to the complete

Table 2. Quantitative Real-Time Polymerase Chain Reaction Primers

\begin{tabular}{llr}
\hline Primer & Forward $\left(\mathbf{5}^{\prime} \mathbf{- 3} \mathbf{3}^{\prime}\right)$ & Reverse $\left(\mathbf{5}^{\prime}-\mathbf{3}^{\prime}\right)$ \\
\hline GAPDH & GAAGGTGAAGGTCGGAGTG & GAAGATGGTGATGGGATTTC \\
CD29 & GCATCCCTGAAAGTCCCAAG & CACTGTCCGCAGACGCACT \\
CD34 & CACCGTGTGTCTCAACATGG & GGCTTCAAGGTTGTCTCTGG \\
CD73 & CAGCGAGGACTCCAGCAAG & TATCCAACGATTCCCACAACT \\
CD90 & CTAGTGGACCAGAGCCTTCG & TGGAGTGCACACGTGTAGGT \\
CD105 & CACTAGCCAGGTCTCGAAGG & CTGAGGACCAGAAGCACCTC \\
\hline
\end{tabular}

GAPDH, glyceraldehyde 3-phosphate dehydrogenase. 

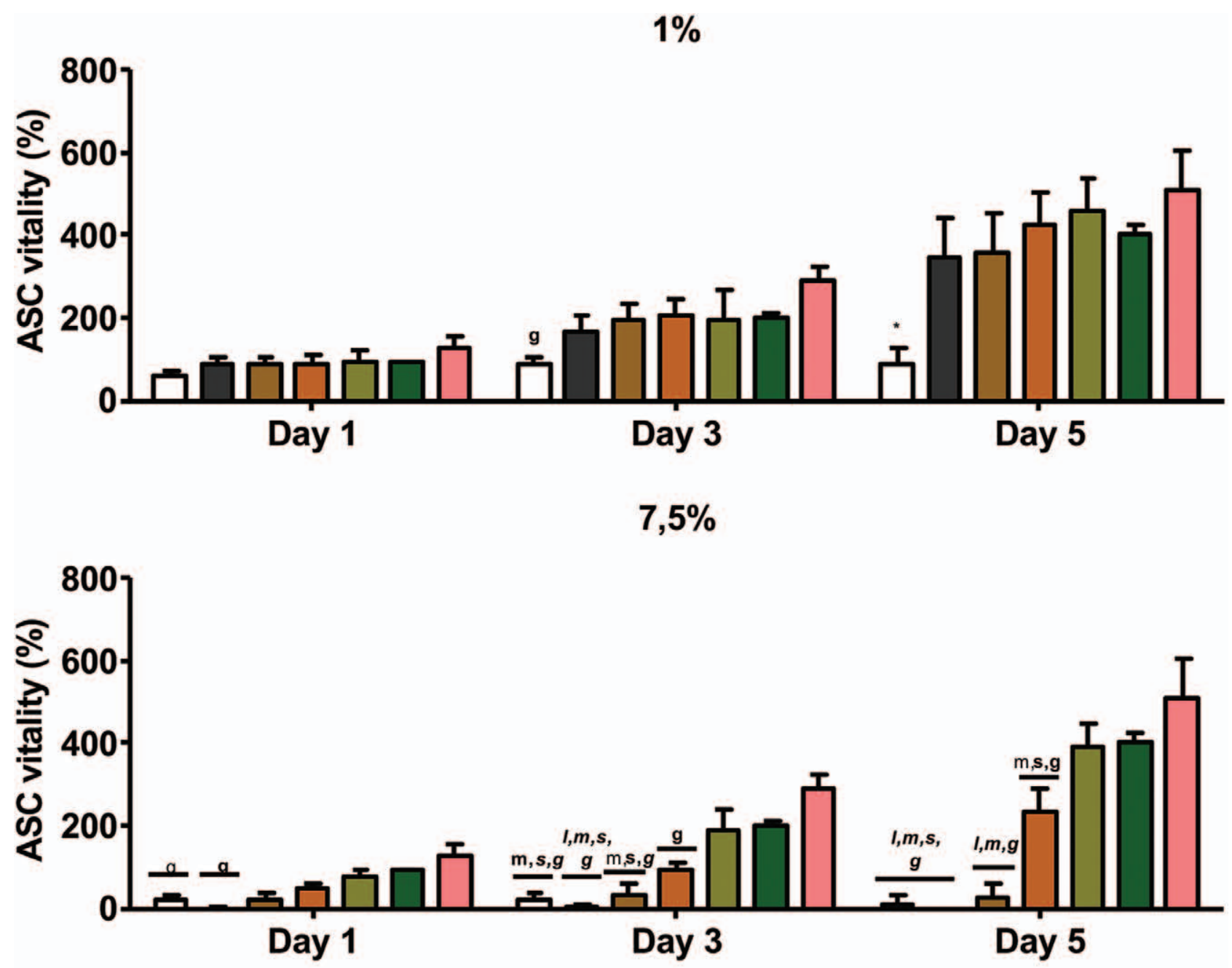

$25 \%$

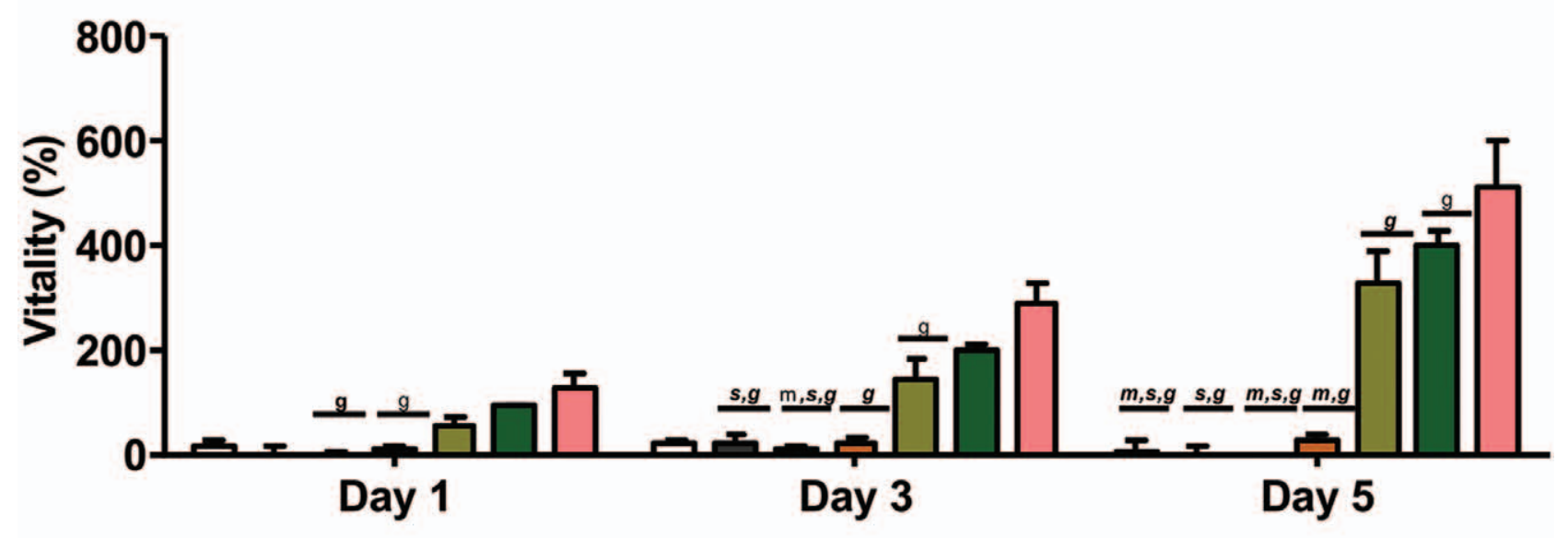

\section{$\square$ Octenisept $\square$ Betaisodona $\square$ Prontosan $\square$ Lavasept $\square$ Mafenide $\square$ Saline $\square$ Growth medium}

Fig. 2. The influence of antiseptics on the viability of adipose-derived stem cells. Cultured adipose-derived stem cells were treated with (above) 1\%, (center) 7.5\%, and (below) 25\% solutions of Octenisept, Betaisodona, Prontosan, Lavasept, mafenide, or normal 
death of adipose-derived stem cells. As the only exception, adipose-derived stem cells survived the treatment with the maximum concentration of $25 \%$ of mafenide acetate. When compared to growth medium, however, adipose-derived stem cells treated with mafenide acetate had significantly decreased viability at $10 \%$ and $25 \%$. Saline only had minimal effect on keratinocyte viability. Our alamarBlue measurements were confirmed by Hoechst staining at day 5 , and representative images of adipose-derived stem cells treated with $7.5 \%$ of the antiseptic/saline/growth medium are shown in Figure 3).

\section{Antiseptics Influence the Proliferation of Adipose-Derived Stem Cells}

Cell proliferation was evaluated by the bromodeoxyuridine assay (Fig. 4, above, left). Because a concentration of $7.5 \%$ showed the most remarkable difference in adipose-derived stem cell viability between the tested antiseptics, we selected this specific concentration for further study, including the bromodeoxyuridine incorporation assay. Similar to the alamarBlue assay, cell proliferation was reduced by all antiseptics and saline. Although saline, Lavasept, and mafenide acetate led to a modest decrease in proliferation, Prontosan, Betaisodona, and Octenisept reduced adipose-derived stem cell proliferation by more than 70 percent.

\section{Antiseptics Influence the Apoptosis and Necrosis of Adipose-Derived Stem Cells}

We investigated the effect of antiseptics on cell death by the annexin $\mathrm{V}$ assay, which allows for the distinction between early/late apoptosis and necrosis (Fig. 4, above, right and Table 3). We compared the ratio between necrosis and apoptosis (sum of early and late apoptosis) and calculated the difference in necrosis between the antiseptics (Table 3). All antiseptics caused increased adiposederived stem cell necrosis compared with growth medium. Octenisept and Betaisodona both led to cell death mainly by necrosis. Prontosan resulted

Fig. 2. (Continued). saline. Growth medium served as a control. The viability of adipose-derived stem cells was evaluated by the alamarBlue assay after 1,3 , and 5 days. The viability of adiposederived stem cells before treatment was set as 100 percent. Data are presented in means \pm SEM. Significant differences when compared to other groups are indicated by letters in lower case. Normal (not bold/italicized), $p<0.05$; bold, $p<0.01$; bold and italicized, $p<0.001 ; o$, Octenisept; $b$, Betaisodona; $p$, Prontosan; l: Lavasept; $m$, mafenide acetate; $s$, saline; $g$, growth medium. in a higher degree of cell death compared with Lavasept, mafenide acetate, and saline, which all induced comparable rates of necrosis and apoptosis.

\section{Antiseptics Influence the Expression of Stem Cell Markers of Adipose-Derived Stem Cells}

CD29, CD34, CD73, CD90, and CD105 mRNA expression was examined by qualitative real-time polymerase chain reaction after treatment with $7.5 \%$ solutions of each antiseptic, saline, medium, staurosporine, hydrogen peroxide, and ultraviolet light (Fig. 5). Although the expression of none of the markers was changed by saline, Betaisodona caused a significant down-regulation of all five stem cell markers (CD34 was not detectable). Octenisept also led to a down-regulation of all markers except for CD105. Lavasept and Prontosan showed a distinctive down-regulation of CD34 and moderate down-regulation of CD29. Mafenide acetate was the only antiseptic that did not influence the expression of any stem cell markers significantly. Staurosporine reduced only CD105 expression, whereas hydrogen peroxide reduced all stem cell markers.

\section{Antiseptics Influence the Adipogenic Differentiation of Adipose-Derived Stem Cells}

The adipogenic differentiation potential of adipose-derived stem cells was examined by Oil Red staining (Fig. 4, below). The low concentration of $0.05 \%$ of antiseptics did not lead to increased cell death as confirmed by the alamarBlue assay. All of the tested antiseptics reduced the adipogenic differentiation of adipose-derived stem cells, whereas saline did not have a significant effect. Under Lavasept, mafenide acetate, and Prontosan treatment, adipogenic differentiation was reduced by almost 40 percent, whereas Betaisodona and Octenisept led to a reduction of almost 80 percent.

\section{DISCUSSION}

Adipose-derived stem cells are pluripotent mesenchymal stem cells located in the adipose tissue and are competent to self-renew, proliferate, and differentiate into multiple cell lines. ${ }^{17}$ Adipose-derived stem cells promote wound repair by differentiation into keratinocytes and fibroblasts, secretion of growth factors, and stimulation of angiogenesis. ${ }^{14,16}$ Because of high yield and easy, safe harvest procedures, adipose-derived stem cells represent a true alternative to bone marrow-derived stem cells. ${ }^{22}$ Improved wound repair by treatment 


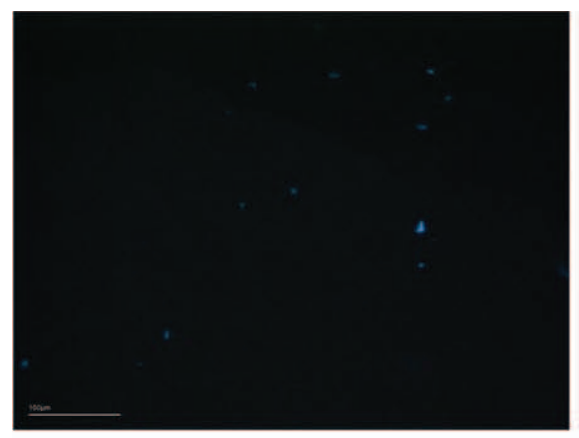

Octenisept

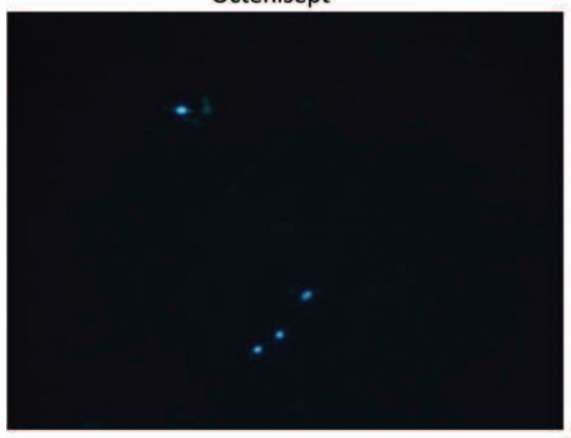

Prontosan

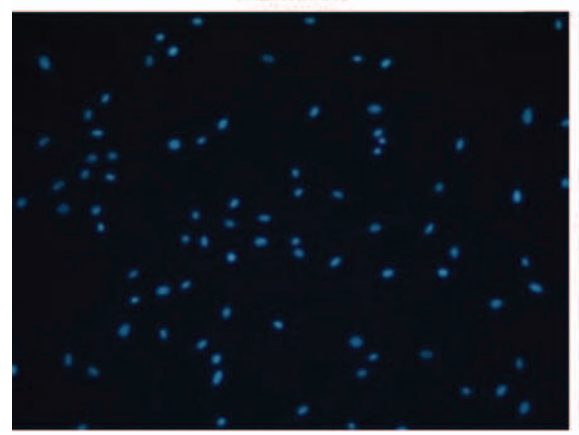

Mafenide

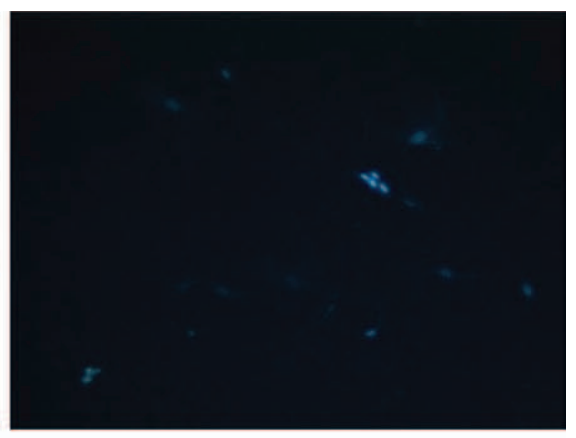

Betaisodona

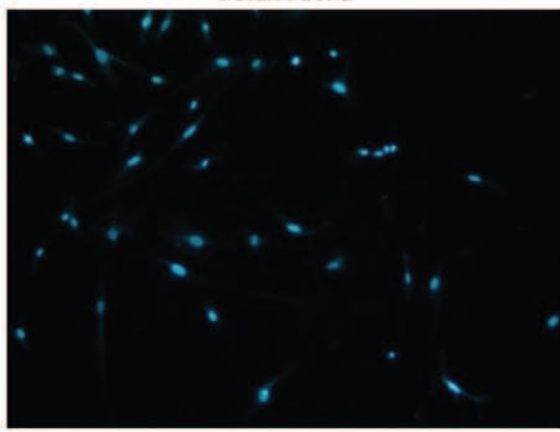

Lavasept

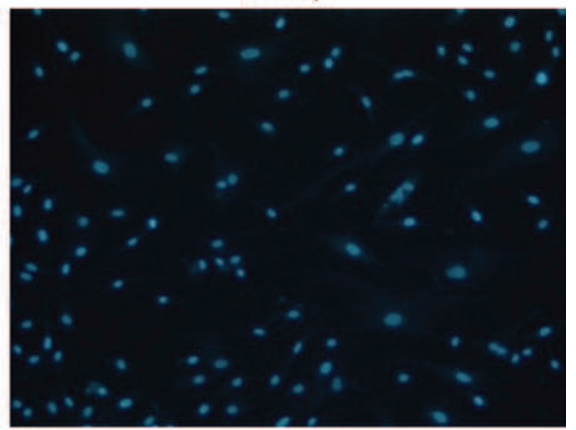

$\mathrm{NaCl}$

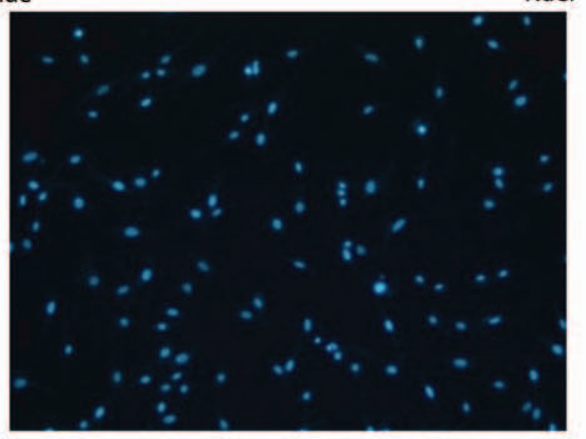

Growth Medium

Fig. 3. After the fifth day of treatment with a $7.5 \%$ solution of antiseptics, adiposederived stem cells were stained by Hoechst 33342 . Hoechst 33342 staining of adiposederived stem cells treated with Octenisept, Betaisodona, Prontosan, Lavasept, Mafenide, normal saline, or growth medium.

with adipose-derived stem cells has been repeatedly reported in a multitude of clinical studies, and interest in the regenerative properties of adipose-derived stem cells continues to increase. ${ }^{2}$ In this study, we have examined the effect of different chemical antiseptics on the viability, proliferation, cell death, expression of stem cell markers, and adipogenic differentiation of adipose-derived stem cells in vitro. 

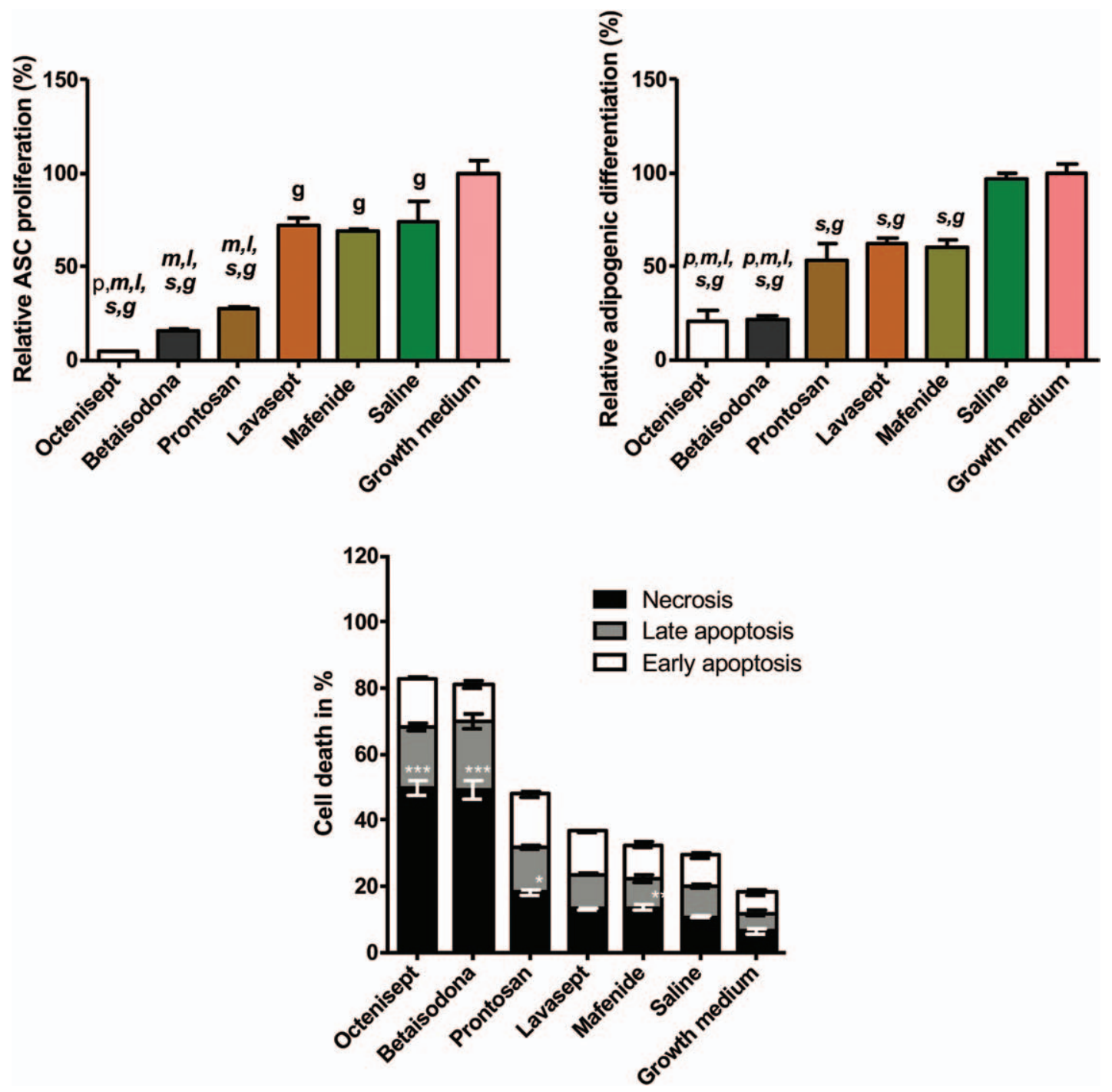

Fig. 4. The influence of antiseptics on proliferation, cell death, and adipogenic differentiation of adiposederived stem cells. Adipose-derived stem cells were treated with a 7.5\% solution of Octenisept, Betaisodona, Prontosan, Lavasept, mafenide acetate, or normal saline. Growth medium served as a control. (Above, left) Adipose-derived stem cell proliferation was measured by the bromodeoxyuridine assay. (Above, right) Cell death was evaluated by the annexin $\mathrm{V}$ assay, which allows a division of cell death into necrosis (7-aminoactinomycin D-positive/annexin V-negative), early apoptosis (7-aminoactinomycin D-positive/annexin V-positive), and late apoptosis (7-aminoactinomycin D-positive/annexin $\mathrm{V}$-positive). The mean $\pm \mathrm{SEM}$ percentages of necrosis, early apoptosis, and late apoptosis are shown. Asterisks mark significant differences between necrosis versus apoptosis (early and late apoptosis). (Below) Adipose-derived stem cell differentiation was analyzed by Oil Red staining after inducing adipogenic differentiation of adipose-derived stem cells by differentiation that was supplemented with $0.05 \%$ solutions of the antiseptics. For above, left and below, data are presented as means \pm SEM. Significant differences when compared to other groups are indicated by letters in lowercase. Normal (not bold/italicized), $p<0.05$; bold, $p<0.01$; bold and italicized, $p<0.001 ; 0$, Octenisept; $b$, Betaisodona; $p$, Prontosan; I, Lavasept; $m$, mafenide acetate; $s$, saline; $g$, growth medium; ASC, adipose-derived stem cell.

Octenisept is a standard antiseptic used in Europe, and is composed of the antiseptic agents octenidine dihydrochloride and phenoxyethanol. However, serositis after peritoneal lavage, severe subcutaneous edema with fatty tissue necrosis in pediatric patients, and chronic soft-tissue inflammation combined with tissue necrosis of the hand have been reported with its use. ${ }^{23-27}$ As a result, the manufacturer issued a warning for the use of Octenisept for the irrigation of deep wounds with high force. In our experiments, Octenisept reduced the viability of 
Volume 139, Number $3 \bullet$ Effect of Antiseptics on Stem Cells

Table 3. Comparison of Necrosis between the Antiseptics, Saline, and Growth Medium*

\begin{tabular}{|c|c|c|c|c|c|c|c|}
\hline & Octenisept & Betaisodona & Prontosan & Lavasept & Mafenide Acetate & Saline & Medium \\
\hline Octenisept & & NS & \pm & \pm & $\ddagger$ & $\ddagger$ & \pm \\
\hline Betaisodona & $\ddagger$ & & \pm & \pm & \pm & \pm & \pm \\
\hline Prontosan & $\stackrel{+}{+}$ & NS & & $\stackrel{+}{N S}$ & NS & + & \pm \\
\hline Lavasept & + & \pm & NS & & NS & NS & $t$ \\
\hline Mafenide acetate & $t$ & \pm & NS & NS & & NS & $t$ \\
\hline Saline & ns & + & + & NS & NS & & $t$ \\
\hline Medium & + & + & \pm & + & + & NS & \\
\hline
\end{tabular}

NS, not significant.

*The necrosis of adipose-derived stem cells was measured by the annexin V assay. Significant differences in necrotic cells necrosis (7-aminoactinomycin D-positive/annexin $\mathrm{V}$-negative) are marked.

$\dagger p<0.05$.

$\pm p<0.001$.

adipose-derived stem cells even when diluted to a $1 \%$ solution, whereas the other tested antiseptics showed marginal to no reduction of viability. Adipose-derived stem cell viability is dependent on cell proliferation, which also was significantly reduced by Octenisept. In contrast to apoptosis, which is a well-controlled form of cell death that may be inhibited by certain measures, Octenisept induces necrosis, an irreversible and therefore more detrimental form of cell death. ${ }^{28,29}$ Necrosis is followed by an inflammatory response, which may further perpetuate the critical condition of wound repair disorders. ${ }^{30}$ Octenisept also reduced the expression of the stem cell markers CD29, CD34, CD90, and CD105. The International Society for Cellular Therapy defined the minimal criteria of cultured mesenchymal stem cells, among others, by the expression of CD73, CD90, and CD105. ${ }^{31}$ CD29 and CD34 are additional surface markers that are used consistently to characterize mesenchymal stem cells. ${ }^{32,33}$ Staurosporine is a well-investigated inducer of apoptosis,${ }^{34}$ whereas high concentrations of hydrogen peroxide induce necrosis. ${ }^{35}$ As the pattern of stem cell marker reduction by Octenisept was similar to that of hydrogen peroxide, necrosis may be the most feasible explanation for Octenisept-related stem cell marker reduction. The capability of adipogenic differentiation, which is a hallmark of adipose-derived stem cells and an important contributor to tissue regeneration, was significantly reduced by Octenisept and may be another deleterious factor associated with its use. ${ }^{17,36}$

Povidone-iodine is the main antiseptic reagent of Betaisodona. ${ }^{37}$ For irrigation, cleansing, and bathing, the manufacturer recommends dilutions of 1:2 to 1:100. Betaisodona showed the second highest reduction of adipose-derived stem cell viability after Octenisept. Betaisodona further reduced adipose-derived stem cell proliferation and differentiation. Betaisodona led to a marked decrease in the expression of all five stem cell markers, which may primarily reflect necrosis of adipose-derived stem cells.

Prontosan and Lavasept are both antiseptic solutions containing the antimicrobial agent polyhexanide. ${ }^{38}$ Prontosan wound irrigation solution is a ready-to-use antiseptic, whereas Lavasept is distributed as a liquid concentrate and its use is recommended in a $0.2 \%$ solution. The cytotoxicity of Prontosan and Lavasept was significantly weaker than that of Octenisept and Betaisodona. The stronger reduction of adipose-derived stem cell viability and proliferation, and the increase of necrosis, by Prontosan compared with Lavasept may be explained by the higher initial concentration, which was $0.1 \%$ polyhexanide compared with $0.04 \%$ polyhexanide in Lavasept. Importantly, CD34+ adipose-derived stem cells are described as being more proliferative and possessing higher stemness. ${ }^{33}$ Both antiseptics reduced the expression of CD34. As neither staurosporine nor hydrogen peroxide led to a similar isolated CD34 reduction, this effect may present a polyhexanidespecific effect.

Mafenide acetate is a short-acting sulfonamide that is provided as a powder. It readily penetrates burn eschar, where it retains its antimicrobial activity even in an acidic environment. Mafenide acetate showed the mildest effect on the viability, proliferation, and cell death of adipose-derived stem cells in our study. Adipose-derived stem cells survived treatment with mafenide acetate even at a concentration of $10 \%$ and $25 \%$. In addition, none of the stem cell markers were significantly altered by mafenide acetate. Since its first use in World War II, mafenide acetate's primary indication has been the antibacterial control of burnrelated wounds/mesh grafts. However, in some 

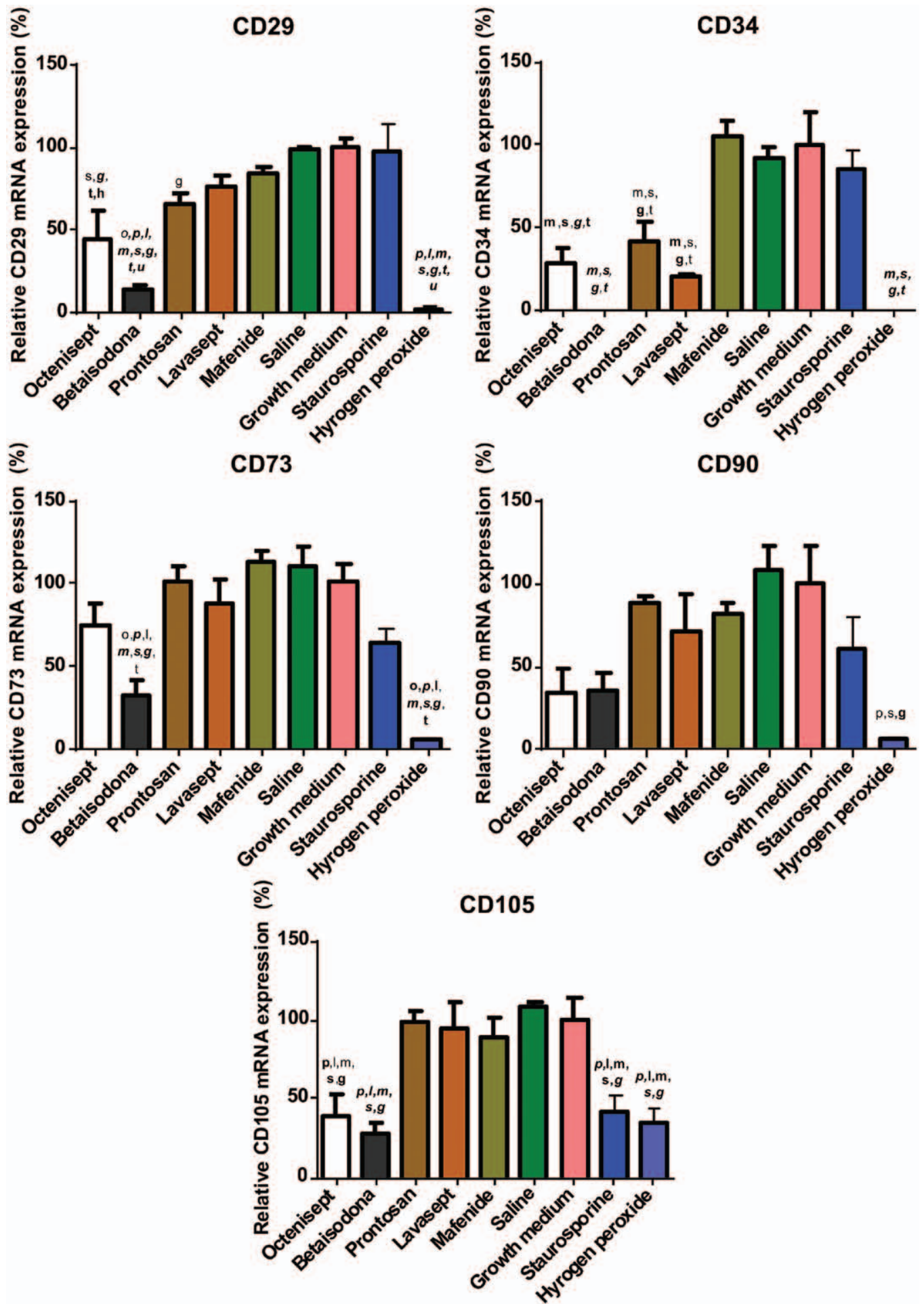

Fig. 5. Expression of stem cell markers after treatment with antiseptics. After treatment of cultured adipose-derived stem cells with Octenisept, Betaisodona, Prontosan, Lavasept, Mafenide, or normal saline, the expression of different stem cell markers was analyzed by qualitative real-time polymerase chain reaction. Growth medium served as a negative control. Staurosporine served as a control for apoptosis, whereas hydrogen peroxide served as a control for necrosis. Expression of mRNA of (above, left) CD29, (above, right) CD34, (center, left) CD73, (center, right) CD90, and (below) CD105 is depicted. Data are presented as means \pm SEM. Significant differences when compared to other groups are indicated by letters in lowercase. Normal (not bold/italicized), $p<0.05$; bold, $p<0.01$; bold and italicized, $p<0.001 ; o$, Octenisept; $b$, Betaisodona; $p$, Prontosan; I, Lavasept; $m$, mafenide; s, saline; $g$, growth medium; $t$, staurosporine; $h$, hydrogen peroxide. 
cases, off-label application of mafenide acetate for the treatment of wounds not related to burns is possible. ${ }^{39,40}$ Bennett et al. demonstrated that mafenide acetate was a highly effective antiseptic in a porcine wound model. ${ }^{4}$ Other studies support the beneficial effect of mafenide acetate on partial-thickness and full-thickness wounds. ${ }^{42,43}$ In chronic wounds reaching the subcutaneous tissue and particularly Pseudomonas aeruginosacolonized wounds, mafenide acetate may represent a genuine alternative to other antiseptics. Drawbacks of mafenide acetate, however, are its high costs and a requirement for use within 48 hours once the powder is reconstituted. ${ }^{44}$

We also examined the effect of saline on adiposederived stem cell viability. Plain saline is commonly used in clinical practice to irrigate wounds, either pure or as a diluent for antibiotics and antiseptics. We have shown that treatment of adipose-derived stem cells with pure saline led to a slight reduction of cell viability and proliferation, and a small increase of cell death, but did not influence stem cell marker expression and adipogenic differentiation. However, its general effectiveness in the prevention of infections is still the subject of debate. ${ }^{45}$ In the context of adipose tissue and adipose-derived stem cell harvest for aesthetic or reconstructive purposes, the use of saline (e.g., to rinse adipose tissue) may be regarded as rather uncritical.

Aside from the toxicity of antiseptics, the antimicrobial potency is pivotal. Interestingly, Müller and Kramer found that Octenisept had superior efficacy against Escherichia coli and Staphylococcus aureus compared with Lavasept, and Betaisodona showed the weakest antimicrobial efficiency. ${ }^{10}$ Hirsch et al. also identified Betaisodona as the least effective antiseptic against $S$. aureus, Enterobacter faecalis, $P$. aeruginosa, and E. coli compared with Octenisept, Prontosan, and Lavasept, all of which showed similar efficiency. ${ }^{6}$ Rode et al. studied the antimicrobial efficiency of mafenide acetate and Betaisodona ointment in rats infected with $P$. aeruginosa and found that mafenide acetate was superior to Betaisodona. ${ }^{46}$ Bennett et al. also reported higher efficiency of mafenide acetate than povidone-iodine-based antiseptics in a porcine burn model. ${ }^{41}$ Collectively, Betaisodona may be the least effective antiseptic, as it shows high adipose-derived stem cell toxicity and relatively low antimicrobial efficiency. Octenisept, by contrast, shows high adipose-derived stem cell toxicity but also high germicidal activity at low concentrations so that a higher dilution may be advocated.

Not only adipose-derived stem cells but also other cells such as keratinocytes and fibroblasts contribute to wound repair. In keratinocytes, Betaisodona and Octenisept showed high cytotoxicity and significant reduction of proliferation, whereas Prontosan and Lavasept exerted only minor effects. ${ }^{6}$ For fibroblasts, controversial results were reported. Müller and Kramer observed the highest cytotoxicity with Octenisept, followed by Lavasept and Betaisodona, ${ }^{10}$ wheras Hirsch et al. showed substantial cytotoxic and antiproliferative effects of Betaisodona and Octenisept but no such effects of Prontosan and Lavasept. ${ }^{6}$ Higher cytotoxic effects on chondrocytes were observed for povidone-iodine-based antiseptics compared with Lavasept. ${ }^{47}$ Consequently, Octenisept and povidone-iodine-based antiseptics appear to be more detrimental to cells than polyhexanidebased antiseptics.

We have to acknowledge some limitations of our study. We have to concede that our data were collected from in vitro experiments. In vitro experiments are surely a valuable approach and a starting point for unraveling underlying mechanisms. Nonetheless, the effects of an in vivo environment where surrounding cells, extracellular matrix, active perfusion, and additional physiologic processes may facilitate clearance of antiseptics and counterregulate toxic effects are neglected. To translate our results into clinical practice (i.e., the treatment of deep wounds), additional studies are needed. Different in vivo wound models ${ }^{48}$ may be used to examine the systemic influences. The harvest and analysis of adipose tissue from patients treated with the different antiseptics may deliver more applicable data and better reflect the in vivo effect of antiseptics on wounds and may therefore be considered in future studies.

\section{CONGLUSIONS}

Mafenide acetate exerted the mildest toxic effects on human adipose-derived stem cells. Lavasept and Prontosan showed moderate toxicity and may be regarded as an alternative to mafenide acetate. Octenisept and Betaisodona, in contrast, reduced adipose-derived stem cell viability, proliferation, and differentiation significantly and caused considerable adipose-derived stem cell necrosis.

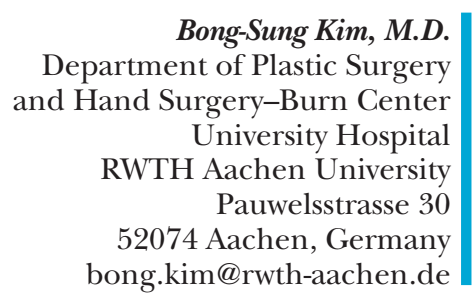




\section{ACIKNOWLEDGMENTS}

Bong-Sung Kim, M.D., is supported by "START," a program for young scientists of the Medical Faculty at the RWTH Aachen University (project number 691346, START 2013-2) and the Research Fellowship Program of the German Research Foundation (Deutsche Forschungsgemeinschaft GZ: KI 1973/1-1). Norbert Pallua, M.D., Ph.D., is supported by Deutsche Forschungsgemeinschaft grant PA 1271/5-1. Jürgen Bernhagen, Ph.D., is supported by Deutsche Forschungsgemeinschaft grants SFB1123/ P03, SFB/TRR57-P07, and DFG BE1977/7-1, and by the Deutsche Forschungsgemeinschaft within the framework of the Munich Cluster for Systems Neurology (EXC 1010 SyNergy). Richard Bucala, M.D., Ph.D., is supported by National Institutes of Health grant R01 AI042310.

\section{REFERENCES}

1. Braiman-Wiksman L, Solomonik I, Spira R, Tennenbaum T. Novel insights into wound healing sequence of events. Toxicol Pathol. 2007;35:767-779.

2. Hassan WU, Greiser U, Wang W. Role of adipose-derived stem cells in wound healing. Wound Repair Regen. 2014;22:313-325.

3. Frank C, Bayoumi I, Westendorp C. Approach to infected skin ulcers. Can Fam Physician 2005;51:1352-1359.

4. Bowler PG, Duerden BI, Armstrong DG. Wound microbiology and associated approaches to wound management. Clin Microbiol Rev. 2001;14:244-269.

5. Daeschlein G. Antimicrobial and antiseptic strategies in wound management. Int Wound J. 2013;10(Suppl 1):9-14.

6. Hirsch T, Koerber A, Jacobsen F, et al. Evaluation of toxic side effects of clinically used skin antiseptics in vitro. J Surg Res. 2010;164:344-350.

7. Thomas GW, Rael LT, Bar-Or R, et al. Mechanisms of delayed wound healing by commonly used antiseptics. J Trauma 2009;66:82-90; discussion 90.

8. Kolbenschlag J, Goertz O, Behr B, Daigeler A, Lehnhardt M, Hirsch T. Skin antiseptics in plastic surgery (in German). Handchir Mikrochir Plast Chir. 2012;44:254-258.

9. Müller G, Kramer A. Comparative study of in vitro cytotoxicity of povidone-iodine in solution, in ointment or in a liposomal formulation (Repithel) and selected antiseptics. Dermatology 2006;212(Suppl 1):91-93.

10. Müller G, Kramer A. Biocompatibility index of antiseptic agents by parallel assessment of antimicrobial activity and cellular cytotoxicity. J Antimicrob Chemother. 2008;61:1281-1287.

11. Sugihara H, Toda S, Yonemitsu N, Watanabe K. Effects of fat cells on keratinocytes and fibroblasts in a reconstructed rat skin model using collagen gel matrix culture. Br J Dermatol. 2001;144:244-253.

12. Aoki S, Toda S, Ando T, Sugihara H. Bone marrow stromal cells, preadipocytes, and dermal fibroblasts promote epidermal regeneration in their distinctive fashions. Mol Biol Cell 2004; 15:4647-4657.

13. Lee SH, Jin SY, Song JS, Seo KK, Cho KH. Paracrine effects of adipose-derived stem cells on keratinocytes and dermal fibroblasts. Ann Dermatol. 2012;24:136-143.

14. Moon KM, Park YH, Lee JS, et al. The effect of secretory factors of adipose-derived stem cells on human keratinocytes. Int J Mol Sci. 2012;13:1239-1257.

15. Campbell CA, Cairns BA, Meyer AA, Hultman CS. Adipocytes constitutively release factors that accelerate keratinocyte proliferation in vitro. Ann Plast Surg. 2010;64:327-332.
16. Kim WS, Park BS, Sung JH, et al. Wound healing effect of adipose-derived stem cells: A critical role of secretory factors on human dermal fibroblasts. J Dermatol Sci. 2007;48:15-24.

17. Zuk PA, Zhu M, Mizuno H, et al. Multilineage cells from human adipose tissue: Implications for cell-based therapies. Tissue Eng. 2001;7:211-228.

18. Toyserkani NM, Christensen ML, Sheikh SP, Sørensen JA. Adipose-derived stem cells: New treatment for wound healing? Ann Plast Surg. 2015;75:117-123.

19. Coleman SR. Structural fat grafts: The ideal filler? Clin Plast Surg. 2001;28:111-119.

20. Grasys J, Kim BS, Pallua N. Content of soluble factors and characteristics of stromal vascular fraction cells in lipoaspirates from different subcutaneous adipose tissue depots. Aesthet Surg J. 2016;36:831-841.

21. Hemmrich K, Kappel BA, Paul NE, et al. Antipsychotic drugs increase adipose stem cell differentiation: Implications for treatment with antipsychotic drugs. J Clin Psychopharmacol. 2011;31:663-665.

22. Kern S, Eichler H, Stoeve J, Klüter H, Bieback K. Comparative analysis of mesenchymal stem cells from bone marrow, umbilical cord blood, or adipose tissue. Stem Cells 2006;24:1294-1301.

23. Hupuczi P, Papp Z. Postoperative ascites associated with intraperitoneal antiseptic lavage. Obstet Gynecol. 2005; 105:1267-1268.

24. Parlakgumus A, Baykal A, Aran O. An unusual cause of chemical peritonitis. Acta Chir Belg. 2005;105:322-323.

25. Hülsemann W, Habenicht R. Severe side effects after Octenisept irrigation of penetrating wounds in children (in German). Handchir Mikrochir Plast Chir. 2009;41:277-282.

26. Schupp CJ, Holland-Cunz S. Persistent subcutaneous oedema and aseptic fatty tissue necrosis after using octenisept. Eur J Pediatr Surg. 2009;19:179-183.

27. Franz T, Vögelin E. Aseptic tissue necrosis and chronic inflammation after irrigation of penetrating hand wounds using Octenisept. J Hand Surg Eur Vol. 2012;37:61-64.

28. Kanduc D, Mittelman A, Serpico R, et al. Cell death: Apoptosis versus necrosis (review). Int J Oncol. 2002;21:165-170.

29. Wang WZ, Fang XH, Williams SJ, et al. Analysis for apoptosis and necrosis on adipocytes, stromal vascular fraction, and adipose-derived stem cells in human lipoaspirates after liposuction. Plast Reconstr Surg. 2013;131:77e-85e.

30. Nikoletopoulou V, Markaki M, Palikaras K, Tavernarakis N. Crosstalk between apoptosis, necrosis and autophagy. Biochim Biophys Acta 2013;1833:3448-3459.

31. Dominici M, Le Blanc K, Mueller I, et al. Minimal criteria for defining multipotent mesenchymal stromal cells. The International Society for Cellular Therapy position statement. Cytotherapy 2006;8:315-317.

32. Davies OG, Cooper PR, Shelton RM, Smith AJ, Scheven BA. Isolation of adipose and bone marrow mesenchymal stem cells using CD29 and CD90 modifies their capacity for osteogenic and adipogenic differentiation. J Tissue Eng. 2015;6:2041731415592356.

33. Suga H, Matsumoto D, Eto H, et al. Functional implications of CD34 expression in human adipose-derived stem/progenitor cells. Stem Cells Dev. 2009;18:1201-1210.

34. Belmokhtar CA, Hillion J, Ségal-Bendirdjian E. Staurosporine induces apoptosis through both caspase-dependent and caspase-independent mechanisms. Oncogene 2001;20:3354-3362.

35. Saito Y, Nishio K, Ogawa Y, et al. Turning point in apoptosis/necrosis induced by hydrogen peroxide. Free Radic Res. 2006;40:619-630.

36. Schmidt BA, Horsley V. Intradermal adipocytes mediate fibroblast recruitment during skin wound healing. Development 2013;140:1517-1527. 
37. Durani P, Leaper D. Povidone-iodine: Use in hand disinfection, skin preparation and antiseptic irrigation. Int Wound J. 2008;5:376-387.

38. Egli-Gany D, Brill FH, Hintzpeter M, Andrée S, Pavel V. Evaluation of the antiseptic efficacy and local tolerability of a polihexanide-based antiseptic on resident skin flora. $A d v$ Skin Wound Care 2012;25:404-408.

39. Breton DW. Off-label drug use in WOC nursing: Issues related to use of mafenide acetate to treat infected chronic wounds. J Wound Ostomy Continence Nurs. 2001;28:253-258.

40. Barillo DJ. Using mafenide acetate in acute and chronic wounds. Ostomy Wound Manage. 2002; (Suppl):5-10.

41. Bennett LL, Rosenblum RS, Perlov C, Davidson JM, Barton RM, Nanney LB. An in vivo comparison of topical agents on wound repair. Plast Reconstr Surg. 2001;108:675-687.

42. Argamaso RV, Garcia A, Freiman M, Lewin ML, Bharati S. Effect of sulfamylon acetate on wound healing. Plast Reconstr Surg. 1970;46:282-286.
43. Kjolseth D, Frank JM, Barker JH, et al. Comparison of the effects of commonly used wound agents on epithelialization and neovascularization. J Am Coll Surg. 1994;179:305-312.

44. Ibrahim A, Fagan S, Keaney T, et al. A simple cost-saving measure: 2.5\% mafenide acetate solution. JBurn Care Res. 2014;35:349-353.

45. Mueller TC, Loos M, Haller B, et al. Intra-operative wound irrigation to reduce surgical site infections after abdominal surgery: A systematic review and meta-analysis. Langenbecks Arch Surg. 2015;400:167-181.

46. Rode H, de Wet PM, Davies MR, Cywes S. An experimental evaluation of the germicidal efficacy of three topical antimicrobial agents in burns. Prog Pediatr Surg. 1981;14:189-208.

47. Schaumburger J, Beckmann J, Springorum HR, et al. Toxicity of antiseptics on chondrocytes in vitro (in German). Z Orthop Unfall. 2010;148:39-43.

48. Ansell DM, Campbell L, Thomason HA, Brass A, Hardman MJ. A statistical analysis of murine incisional and excisional acute wound models. Wound Repair Regen. 2014;22:281-287. 